\title{
Variability in ejaculation rate and libido of boars during reproductive exploitation
}

\author{
R. Savić \& M. Petrović \\ University of Belgrade, Faculty of Agriculture, Institute of Zootechnics, \\ Nemanjina 6, 11080 Belgrade-Zemun, Republic of Serbia
}

(Received 17 January 2014; Accepted 6 July 2015; First published online 29 August 2015)

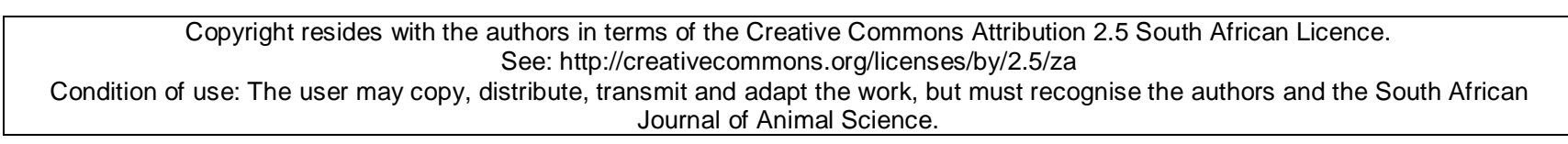

\begin{abstract}
The main objective of the study was to evaluate variability in the ejaculation rate and libido of boars under various genetic and non-genetic influences. A total of 7171 semen samples were collected from Swedish Landrace, Large White and Duroc boars reared under commercial production conditions. Time spent in preparing or collecting, constituted the period from the entry of boars into the room for collecting semen to onset of ejaculation. Ejaculation rate was defined as the volume of sperm extracted $(\mathrm{mL})$ per unit of time (min). The index of boar libido was defined as the relationship between productive (duration of ejaculation) and unproductive (time spent in preparing to collect/jump) periods. Average values of the interval between two collections, age of boar at collection, time spent in preparing for collection, duration of ejaculation, volume of ejaculate, rate of ejaculation and libido index were: 8.83 days, 551.2 days, 3.56 min, $6.06 \mathrm{~min}, 231.9 \mathrm{~mL}, 37.67 \mathrm{~mL} / \mathrm{min}$ and 1.76 , respectively. Ejaculate traits and libido varied according to breed, season and collector, with the exception of seasonal variability of duration of ejaculation. The regression effect of the interval between two collections of ejaculate and age of boar at collection was not statistically significant only for duration of preparing for collection. Unlike the ejaculation rate, during the summer and autumn periods, boars exhibited weaker libido than in winter and spring. Duroc boars were inferior to the fertile breeds (Swedish Landrace and Large White) in terms of shorter duration of ejaculation, lower volume, lowest rate of ejaculation and weakest libido. Variability of rate of ejaculation and of boar libido indicates the need to include these traits in breeding programmes and the possibility of improving these traits.
\end{abstract}

Keywords: Breed, ejaculate, libido index, pig, season, swine, variability

\#Corresponding author: savic@agrif.bg.ac.rs

\section{Introduction}

Modern pig production is characterized by animals of high genetic potential and modern facilities and equipment that reduce human involvement in the production process and increase productivity. The welfare and wellbeing of animals are often neglected, there by instigating forms of abnormal behaviour or having a depressing effect on the expression of desirable traits. A review of the literature did not reveal a standardized procedure for assessing the sexual behaviour of boars that are used for artificial insemination. In addition, knowledge of the impact of sexual behaviour on the reproductive performance of boars is significantly sparser than that of the physiological mechanism of sperm production (Levis \& Reicks, 2005). Sexual behaviour of males depends on the interaction between the organism and the environment (Wysokińska \& Kondracki, 2014). Expression of libido is influenced by genetic and hormonal factors, and by paragenetic impacts (social environment, season, accommodation, training of boars to jump), so that changes in libido may indirectly indicate technological deficiencies (bad microclimate, fattening conditions, exposure to stress, and poor training of workers that manipulate the animals). Boar reproductive performance (quality of ejaculate, fertility and sexual behaviour) shows special seasonal changes (Pinart \& Puigmulé, 2013).

Since boars are bred primarily for traits that have economic importance (weight gain, leanness, fertility), it is necessary to take into account the presence of sex drive as one of the most important criteria when choosing boars. There are differences between breeds and lines of pigs in libido and sexual behaviour, as well as duration of boar ejaculation (Okere et al., 2005).

According to various studies, libido score is based on the duration of preparation for the collection/jump, duration of erection, time from entry into the room with the dummy sow to onset of 
ejaculation, ejaculation duration or total time from entering the room for the collection of semen to the end of ejaculation (Okere et al., 2005; Szostak \& Sarzyńska, 2011; Oberlender et al., 2012; Kondracki et al., 2013; Wysokińska \& Kondracki, 2014). In the research by Estienne \& Harper (2004), libido was assessed, based on reaction time (interval from entering the room for collecting semen to early ejaculation) and duration of ejaculation.

Assessment of libido based only on the duration of ejaculation is insufficient, so it is necessary to take into account the period before collection. When the assessment of libido is based on the total duration of the period from entry into the room with the dummy sow until the end of ejaculation (total manipulation time) the period of boar preparation is not separated from the duration of ejaculation. The manifestations of boar sex drive are complex and require a different definition of libido and analysis of additional properties during the reproductive life of boars. During ejaculation, negative impacts of external factors (temperature, bacterial or mechanical contamination, etc.) on ejaculate are possible, so most of the boar ejaculate volume should be excreted in the shortest possible time.

The aim of this study was to evaluate various genetic and non-genetic impacts on the rate of ejaculation and on boar libido during reproductive exploitation.

\section{Materials and Methods}

The study included 7171 collections (semen samples) from 105 boars of three breeds: Swedish Landrace (SL), Large White (LW) and Duroc (D).

The collections that were analysed were from boars reared under intensive production (farm) conditions for nine years (2004 - 2012). The influence of season was determined by using samples collected from boars in winter, spring, summer and autumn. Boars from which samples had not been collected in all four seasons were excluded from the analysis. Throughout the study period, eight people were used to collect the samples. Of the total number of semen collections, 161 sessions did not yield samples, and were thus not included in the analysis and libido assessment. The boars had no social restriction during the experimental period.

A digital timer was used to measure the time intervals in minutes $(\mathrm{min})$. These data were used: interval between collections (IBC, day), age of boars at collecting (A, day), time spent in preparing for collection ( $T$, $\mathrm{min}$ ), duration of ejaculation $(\mathrm{E}, \mathrm{min})$, and volume of ejaculate (VOL, $\mathrm{mL})$. Time spent in preparing for collection was calculated from the entry of boars into the room for collecting semen to the onset of ejaculation. The ejaculate was taken with the gloved hand method. Ejaculate volume was measured with a graduated cylinder, with accuracy of $\pm 10 \mathrm{~mL}$. The process of ejaculation in boars is multiphase and the first phase is pre-spermal (gel fraction), the ejaculate has clear seminal fluid with dead sperm cells, and is heavily contaminated with bacteria. This gel fraction was not collected. formula:

Based on VOL and E, the rate of ejaculation $(F)$ was calculated for each collection, according to this

$$
F=V O L / E
$$

and defined as the volume of extracted semen per unit of time $(\mathrm{mL} / \mathrm{min})$.

It was assumed that longer duration of ejaculation and shorter preparatory time are indicators of a good libido. Preparing to collect is a non-productive period (NP) within the total manipulative time, which is calculated from when a boar enters the room with the dummy sow until the end of ejaculation. The productive period (PP) is defined as the time during which the boar ejaculates. Libido may be defined as the ratio of productive to non-productive period, based on this formula:

$$
\mathrm{I}=\mathrm{PP} / \mathrm{NP}
$$

and obtained numerical value representing the libido index (I).

The impact of factors was evaluated using the REML procedure in statistical package SAS 9.1.3 (SAS, 2002-2003), by applying these mixed models:

$$
\begin{aligned}
& Y_{i j k l m}=\mu+B_{i}+G_{j}+S_{k}+C_{l}+\beta_{1}\left(x_{i j k l m}-\bar{x}\right)+\beta_{1}\left(x_{i j k l m}-\bar{x}\right)^{2}+\beta_{2}\left(x_{i j k l m}-\bar{x}\right)+\varepsilon_{i j k l m} \\
& Y_{i j k l m}=\mu+B_{i}+G_{j}+S_{k}+C_{l}+\beta_{1}\left(x_{i j k l m}-\bar{x}\right)+\beta_{2}\left(x_{i j k l m}-\bar{x}\right)+\varepsilon_{i j k l m}
\end{aligned}
$$

where $Y_{i j k l m}$ : observed trait; $\mu$ : general population average; $B_{i}$ : random boar impact $(i=1,2,3 \ldots 105) ; G_{j}$ : fixed effect of breed $(j=1,2,3) ; S_{k}$ : fixed effect of season $(k=1,2,3,4) ; C_{l}$ : fixed effect of the collector $(I=$ $1,2,3,4,5,6,7,8) ; \beta_{1}\left(x_{i j k l m}-\bar{x}\right)$ : linear regression effect of the interval between the successful collections; 
$\beta_{1}\left(x_{i j k l m}-\bar{x}\right)^{2}$ : regression effect of the interval between two successful collections squared; $\beta_{2}\left(x_{i j k l m}-\bar{x}\right)$ : linear regression effect of the boar age at semen/ejaculate collection; and $\varepsilon_{i j k l m}$ : random error.

The first model was used to assess duration of ejaculation, ejaculate volume and rate of ejaculation and the second model to evaluate boar preparation time for collection and their libido index. Testing (comparison) between least square means (LSM) values was performed by t-test, and comparisons were made only for the main fixed effects of season and breed. Effect of collector was analysed in terms of deviation from the general population average.

Libido was assessed/scored using the values of 1 to 5 , with scores 1 and 5 being determined by the absolute deviation of -2 SD and +2 SD from the mean phenotypic value, and through uniform distribution of intervals designated by scores 1 and 5 into the three segments. Other scores were defined $(2,3,4)$. The libido of each collection during the reproductive exploitation was assessed.

\section{Results and Discussion}

The statistical parameters of the traits/properties of boars are presented in Table 1. The average/mean age of the boars when taking the ejaculate was 551.2 days. In relation to the other traits, boar age exhibited the largest degree of variation. The frequency of boar utilization was 41.3 collections per year, since the average interval between two collections was 8.83 days. The average VOL of ejaculate was $231.9 \mathrm{~mL}$, with a wide variation range of $50 \mathrm{~mL}$ to $810 \mathrm{~mL}$. $\mathrm{mL} / \mathrm{min}$.

A wide variation interval was detected in the expression of ejaculation rate of $8.33 \mathrm{~mL} / \mathrm{min}$ to 101.3

Table 1 Statistical parameters of boar ejaculate traits and libido

\begin{tabular}{lcccccc}
\hline Traits & N & Mean & SD & Min & Max & CV (\%) \\
\hline Interval between two successive collections, day & 6966 & 8.83 & 3.51 & 1 & 21 & 39.73 \\
Age of the boars with the ejaculate, day & 7171 & 551.2 & 232.6 & 161.0 & 1080 & 42.20 \\
Duration of preparing for the collection, $\min$ & 6760 & 3.56 & 0.63 & 2 & 7 & 11.75 \\
Duration of ejaculation, min & 6754 & 6.06 & 0.69 & 3 & 8 & 11.35 \\
Volume of ejaculate, $\mathrm{mL}$ & 6784 & 231.9 & 74.0 & 50 & 810 & 31.90 \\
Rate of ejaculation, $\mathrm{mL} / \mathrm{min}$ & 6753 & 37.67 & 8.82 & 8.33 & 101.3 & 23.40 \\
Libido index & 6754 & 1.76 & 0.41 & 0.67 & 4.00 & 22.99 \\
\hline
\end{tabular}

N: number of ejaculates; SD: standard deviation; Min: minimum; Max: maximum; CV: coefficient of variation.

The average ejaculation rate of $37.67 \mathrm{~mL} / \mathrm{min}$ in this study is similar to the results of Oberlender et al. (2012), in which the average duration of the ejaculation is 378.2 seconds $(6.30 \mathrm{~min})$, and the average VOL is $251.3 \mathrm{~mL}$, indicating the value of $\mathrm{F}$ as $39.9 \mathrm{~mL} / \mathrm{min}$. In the research by Estienne \& Harper (2004), duration of ejaculation was longer in boars treated with hormone PGF2 $\alpha$ compared with the control group (459.1 \pm $24.1 \mathrm{~s}$ compared with $303.1 \pm 24.1 \mathrm{~s}$ ), and the hormone treatment reduced the $T$ value.

The traits/properties of boars varied according to the influence of genetic and paragenetic factors (Table 2). With an increase in IBC of 1 day, at a constant $A, F$ increased by $0.7576 \mathrm{~mL} / \mathrm{min}$ and the libido index (I) by 0.0035 . As boar age increased, sperm production was augmented. The values of regression coefficients of boar age when taking the ejaculate compared with regression coefficients of IBC were lower, but they had positive values, indicating a linear increase in $\mathrm{F}$ and the index of libido (I) with increasing age of boars.

There was partial similarity in the variability of VOL in the present study with the research of Okere et al. (2005), in which the VOL varied under the influence of season and breed, but boar libido did not. The results of the present study were consistent with the research of Szostak \& Sarzyńska (2011), who found statistically significant differences between breeds in the average expression and variability of libido. There was a tendency towards increase in ejaculate volume with age of boar, which was similar to the results presented by Jankevičiûtė \& Žilinskas (2002), Wolf \& Smital (2009a; b), Banaszewska \& Kondracki (2012) and Savić et al. (2013). In the research of Frangež et al. (2005), the best libido was manifested when the ejaculate was collected twice a week, whereas shortening the interval between two collections resulted in a decline in libido. On the other hand, Szostak \& Sarzyńska (2011) found more pronounced exhibition of libido 
in younger boars, which decreased with the increasing age of boars. Unlike these results, the study by Tomiyama et al. (2008) found no regression effect of age on variability of volume of ejaculate.

Table 2 Significance of effects of breed, season and collector and estimated parameters of boar ejaculate and libido traits

\begin{tabular}{|c|c|c|c|c|c|c|c|c|}
\hline \multirow{3}{*}{ Traits } & \multirow{3}{*}{$\begin{array}{l}\text { Pop. } \\
\text { average }\end{array}$} & \multicolumn{6}{|c|}{ Effects } & \multirow{3}{*}{$\begin{array}{l}\text { Intercept } \\
\text { (a) }\end{array}$} \\
\hline & & \multirow{2}{*}{ Breed } & \multirow{2}{*}{ Season } & \multirow{2}{*}{ Collector } & \multicolumn{2}{|c|}{$\begin{array}{l}\text { Interval between two } \\
\text { successive collection }\end{array}$} & \multirow{2}{*}{$\begin{array}{c}\begin{array}{c}\text { Age of } \\
\text { boars }\end{array} \\
\beta_{2}\end{array}$} & \\
\hline & & & & & $\beta_{1}$ & $\beta_{1}^{2}$ & & \\
\hline $\mathrm{T}, \min$ & 3.54 & * & ** & $\star * * *$ & $-0.0004^{\mathrm{ns}}$ & - & $0.0001^{\mathrm{ns}}$ & $3.5867^{\star \star \star}$ \\
\hline $\mathrm{E}, \min$ & 6.08 & $\star \star$ & ns & $* * \star$ & $0.0533^{\star \star \star}$ & $-0.0022^{\star \star \star}$ & $0.0001^{\star \star \star}$ & $5.2279^{\star \star \star}$ \\
\hline VOL, mL & 235.2 & $\star *$ & 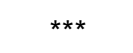 & $\star \star * \star$ & $5.9826^{\star \star \star}$ & $-0.2463^{\star \star \star}$ & $0.0828^{\star \star \star}$ & $135.54^{\star \star \star}$ \\
\hline $\mathrm{F}, \mathrm{mL} / \mathrm{min}$ & 38.03 & $\star \star *$ & $\star * \star *$ & $\star * \star *$ & $0.7576^{\star \star \star}$ & $-0.0316^{\star \star \star}$ & $0.0092^{\star \star \star}$ & $26.4258^{\star \star \star}$ \\
\hline $\begin{array}{l}\text { Libido } \\
\text { index }\end{array}$ & 1.78 & * & * & *** & $0.0035^{\star \star}$ & - & $0.0002^{\star \star \star}$ & $1.5584^{\star \star \star}$ \\
\hline
\end{tabular}

Pop.: population; T: duration of preparing for the collection; E: duration of ejaculation; VOL: volume of ejaculate; F: rate of ejaculation; $\beta_{1}, \beta_{2}$ : linear regression coefficients; $\beta_{1}{ }^{2}$ : linear regression coefficients on the square.

${ }^{n s}$ not significant $(P>0.05)$; ${ }^{*}$ statistical significance at $P<0.05$; ${ }^{* *}$ statistical significance at $P<0.01$;

${ }^{\star * \star}$ statistical significance at $P<0.001$.

The effect of season on the variability of these traits of boars and comparisons between seasons are shown in Table 3.

During winter and spring, the preparation time of boars before collection was shorter, but the VOL of ejaculate was below the population average. Volume of ejaculate in autumn was higher by $9.09 \mathrm{~mL}$ $(P<0.001)$, and the preparation time of boars before collection was longer by $0.05 \mathrm{~min}(P<0.01)$ than in the spring period. The rate of ejaculation $(F)$ was lower in winter and spring than in summer and autumn. The rate of ejaculation in autumn was higher $(P<0.001)$ by $1.05 \mathrm{~mL} / \mathrm{min}$ compared with spring, and higher $(P<0.01)$ by $0.78 \mathrm{~mL} / \mathrm{min}$ compared with winter. The reason for the highest $\mathrm{VOL}$ and best $\mathrm{F}$ in autumn might be the stimulating effect of the shorter photoperiod on the neurohumoral mechanism of production of sperm. Unlike F, in summer and autumn, because of the negative impact of high temperatures and the incidence of chronic stress, boars exhibited weaker libido (below average) owing to the long time spent in preparing for collection (NP).

Table 3 Comparison of least square means $( \pm$ SEM) of traits of boar ejaculate and libido between seasons

\begin{tabular}{|c|c|c|c|c|c|}
\hline \multirow[b]{2}{*}{ Season } & \multicolumn{5}{|c|}{ Traits } \\
\hline & $\begin{array}{c}\text { Duration of preparing } \\
\text { for the collection } \\
\text { (min) }\end{array}$ & $\begin{array}{c}\text { Duration of } \\
\text { ejaculation (min) }\end{array}$ & $\begin{array}{c}\text { Volume of } \\
\text { ejaculate }(\mathrm{mL})\end{array}$ & $\begin{array}{l}\text { Rate of ejaculation } \\
(\mathrm{mL} / \mathrm{min})\end{array}$ & $\begin{array}{l}\text { Libido } \\
\text { index }\end{array}$ \\
\hline Winter & $3.52^{\mathrm{a}, \mathrm{Cc}} \pm 0.03$ & $6.09 \pm 0.03$ & $234.23^{\mathrm{Aa}} \pm 3.99$ & $37.81^{\mathrm{Aa}} \pm 0.46$ & $1.79^{a} \pm 0.02$ \\
\hline Spring & $3.51^{\mathrm{Aa}} \pm 0.03$ & $6.06 \pm 0.03$ & $230.69^{\mathrm{Aa}, \mathrm{Cc}, \mathrm{A}} \pm 3.99$ & $37.54^{\mathrm{a}, \mathrm{A}} \pm 0.46$ & $1.79^{a} \pm 0.02$ \\
\hline Summer & $3.57^{\mathrm{b}, \mathrm{Bb}} \pm 0.03$ & $6.08 \pm 0.03$ & $236.08^{\mathrm{Dd}} \pm 3.98$ & $38.17^{b} \pm 0.46$ & $1.76^{b} \pm 0.02$ \\
\hline Autumn & $3.56^{\mathrm{Bb}, \mathrm{Dd}} \pm 0.03$ & $6.11 \pm 0.03$ & $239.78^{\mathrm{Bb}, \mathrm{B}} \pm 3.96$ & $38.59^{\mathrm{Bb}, \mathrm{B}} \pm 0.46$ & $1.77 \pm 0.02$ \\
\hline
\end{tabular}

Means within a column with different superscripts differ (a,b at $P<0.05 ; \mathrm{Aa}, \mathrm{Bb}$ at $P<0.01$; $\mathrm{Cc}, \mathrm{Dd}$ at $P<0.01$;

$\mathrm{A}, \mathrm{B}$ at $P<0.001)$.

Non-compliance of our research with the study by Okere et al. (2005), in which boar libido did not vary under the influence of season, may be owing to the different method that was used. In assessing libido, 
these authors considered the time needed for collection, ejaculation time and erection time. Defined minimum value of VOL during the spring period $(230.69 \mathrm{~mL})$ was consistent with the studies of Okere et al. (2005), Frydrychová et al. (2007), Kondracki et al. (2009) and Wolf \& Smital (2009a), who found that in spring the lowest volume of ejaculate was recorded in these breeds. Contrary to this study, Tomiyama et al. (2008) registered the largest VOL in spring, while in autumn the ejaculate volume was lowest.

In Table 4, deviations are shown of the phenotypic traits of boars from the general population average ( $\mu$ ) according to workers (collectors) who handled boars.

Table 4 Deviation of boar ejaculate and libido traits of the general population average $(\mu)$ by collectors

\begin{tabular}{|c|c|c|c|c|c|}
\hline \multirow[b]{2}{*}{ Collector (C) } & \multicolumn{5}{|c|}{ Traits } \\
\hline & $\begin{array}{c}\text { Duration of preparing } \\
\text { for the collection } \\
\text { (min) }\end{array}$ & $\begin{array}{c}\text { Duration of } \\
\text { ejaculation (min) }\end{array}$ & $\begin{array}{c}\text { Volume of } \\
\text { ejaculate }(\mathrm{mL})\end{array}$ & $\begin{array}{l}\text { Rate of ejaculation } \\
\text { (mL/min) }\end{array}$ & $\begin{array}{r}\text { Libido } \\
\text { index }\end{array}$ \\
\hline 1 & 0.02 & 0.07 & 13.78 & 1.54 & 0.00 \\
\hline 2 & 0.09 & 0.01 & 10.44 & 1.85 & -0.04 \\
\hline 3 & 0.12 & 0.12 & -4.67 & -1.4 & 0.08 \\
\hline 4 & -0.10 & -0.18 & -26.35 & -3.19 & 0.00 \\
\hline 5 & 0.01 & -0.24 & -22.52 & -2.37 & -0.07 \\
\hline 6 & -0.01 & 0.13 & 22.38 & 3.19 & 0.04 \\
\hline 7 & 0.11 & 0.19 & 18.45 & 1.76 & -0.01 \\
\hline 8 & 0.03 & -0.06 & -11.54 & -1.41 & -0.03 \\
\hline$\mu$ & 3.54 & 6.08 & 235.20 & 38.03 & 1.78 \\
\hline
\end{tabular}

These deviations indicate differences between workers in handling animals. For Worker 4, boars exhibited the shortest preparatory period for collection $(-0.10 \mathrm{~min})$, but the VOL of ejaculate was lowest (by $26.35 \mathrm{~mL}$ compared with the average). In contrast, Worker 6 achieved the best results. That is, boars had a higher ejaculate VOL $(+22.38 \mathrm{~mL})$, higher rate of ejaculation $(+3.19 \mathrm{~mL} / \mathrm{min})$ and higher value of libido index $(+0.04)$ than the general average. These differences are caused by levels of skills and training and different approaches to the operations, from guiding boars to the room with the dummy sow, to taking the sperm.

Comparison of LSM between breeds is shown in Table 5. Large White boars showed superiority in $\mathrm{E}$ (+0.22 $\mathrm{min}, P<0.01)$, VOL $(+28.77 \mathrm{~mL}, P<0.01)$, and $\mathrm{F}(+3.29 \mathrm{~mL} / \mathrm{min}, P<0.01)$, compared with $\mathrm{D}$ boars. When it came to libido, SL boars had better sex drive. That is, the PP to NP ratio was higher $(P<0.05)$ by 0.10 and 0.12 index points, compared with LW and D boars, respectively. The main reason for pronounced libido in SL boars is the result of the shorter duration of preparing for the collection. Duroc boars were inferior to the fertile breeds (LW and $\mathrm{SL}$ ) in both traits/properties with the lowest rate of ejaculation (36.27 $\mathrm{mL} / \mathrm{min})$ and the weakest libido (1.73).

Table 5 Comparison of least square means $( \pm$ SEM) of boar ejaculate and libido traits between breeds

\begin{tabular}{|c|c|c|c|c|c|}
\hline \multirow[b]{2}{*}{ Breed } & \multicolumn{5}{|c|}{ Traits } \\
\hline & $\begin{array}{c}\text { Duration of } \\
\text { preparing for the } \\
\text { collection (min) }\end{array}$ & $\begin{array}{c}\text { Duration of } \\
\text { ejaculation } \\
\text { (min) }\end{array}$ & $\begin{array}{c}\text { Volume of } \\
\text { ejaculate }(\mathrm{mL})\end{array}$ & $\begin{array}{c}\text { Rate of } \\
\text { ejaculation } \\
\text { (mL/min) } \\
\end{array}$ & Libido index \\
\hline Swedish Landrace & $3.43^{\mathrm{Aa}} \pm 0.05$ & $6.09 \pm 0.05$ & $237.46 \pm 6.50$ & $38.25 \pm 0.75$ & $1.85^{a} \pm 0.03$ \\
\hline Large White & $3.64^{\mathrm{Bb}} \pm 0.05$ & $6.19^{\mathrm{Aa}} \pm 0.05$ & $248.45^{\mathrm{Aa}} \pm 6.11$ & $39.56^{\mathrm{Aa}} \pm 0.70$ & $1.75^{b} \pm 0.03$ \\
\hline Duroc & $3.56 \pm 0.05$ & $5.97^{\mathrm{Bb}} \pm 0.05$ & $219.68^{\mathrm{Bb}} \pm 6.69$ & $36.27^{\mathrm{Bb}} \pm 0.77$ & $1.73^{b} \pm 0.03$ \\
\hline
\end{tabular}

Means within a column with different superscripts differ (a,b at $P<0.05$; Aa,Bb at $P<0.01 ; \mathrm{A}, \mathrm{B}$ at $P<0.001$ ). 
Statistically significant differences in T between boars LW and SL are similar to those found in the research of Szostak \& Sarzyńska (2011). However, in their study T is higher in Polish Landrace boars (6.30 min) compared with Polish LW (5.31 min). The results of the present study are not in accordance with the examination carried out by Okere et al. (2005), in which the significant superiority of Yorkshire boars compared with Landrace was determined in ejaculate volume (336.05 to $144.42 \mathrm{~mL}$ ). There was also inconsistency in the assessment of libido, as Okere et al. (2005) recorded weaker libido in Landrace compared with Yorkshire boars during different seasons, but these differences were not significant. Contrary to the present study, in the research of Szostak \& Sarzyńska (2011), total time (T + E) was shorter in Polish LW boars (10.4 $\mathrm{min})$ compared with Polish Landrace (12.6 $\mathrm{min})$, and the best libido was found in hybrid boars (6.47 $\mathrm{min}$ ) and Duroc $(7.05 \mathrm{~min})$. This discrepancy was the result of differences in the genetic structure of the population, housing technologies, and in the way in which the libido of boars was defined and evaluated.

Most of the collections from boars in this period received an average score of 3 (Table 6), and the number of collections is presented based on the average value of I (the average PP and NP ratio) during reproductive exploitation.

Table 6 Number of mountings $\left(\mathrm{N}_{\mathrm{i}}\right)$ per estimate of the libido

\begin{tabular}{ccr}
\hline Estimate of the libido & Libido index (I) & $\mathbf{N}_{\mathbf{i}}$ \\
\hline 5 & $>2.58$ & 282 \\
4 & $2.04-2.58$ & 462 \\
3 & $1.49-2.03$ & 5444 \\
2 & $0.94-1.48$ & 563 \\
1 & $<0.94$ & 3 \\
\hline
\end{tabular}

This method of assessment of libido is applicable to practical breeding and selection, and the distribution of the numbers of collections according to libido assessment indicates the possibility of improving libido through selection and application of various stimuli, while eliminating the influence of depressive effects on the sexual activity of boars.

\section{Conclusion}

The traits/properties of the boars varied because of genetic and paragenetic influences, with the exception of seasonal variability of duration of ejaculation. The variability of the rate of ejaculation and of boar libido indicates the need to include these traits in breeding programmes. Definition of libido as a relationship between the productive (duration of ejaculation) and non-productive (time spent in preparing to collect) periods appears to be the best way to describe the distribution of the total time required for collection of semen from boars. Analysis of additional properties such as ejaculation rate is important, because during ejaculation negative impacts of external factors on the ejaculate are possible, so it is advisable for a boar to excrete a greater volume of ejaculate in the shortest possible time.

\section{Acknowledgement}

Research was financed by the Ministry of Education, Science and Technological Development of the Republic of Serbia, project TR 31081.

\section{References}

Banaszewska, D. \& Kondracki, S., 2012. An assessment of the breeding maturity of insemination boars based on ejaculate quality changes. Folia Biologica (Kraków) 60, 151-162.

Estienne, M.J. \& Harper, A.F., 2004. Semen characteristics and libido in boars treated repeatedly with PGF $_{2 \alpha}$. J. Anim. Sci. 82, 1494-1498.

Frangež, R., Gider, T. \& Kosec, M., 2005. Frequency of boar ejaculate collection and its influence on semen quality, pregnancy rate and litter size. Acta vet. Brno. 74, 265-273.

Frydrychová, S., Lustyková, A., Čerovský, J., Lipenský, J. \& Rozkot, M., 2007. Seasonal changes of boars semen production. Research in Pig Breeding 1, 31-33. 
Jankevičiûtè, N. \& Žilinskas, H., 2002. Influence of some factors on semen quality of different breeds of boars. Veterinarija ir zootechnika 19, 15-19.

Kondracki, S., Wysokińska, A., Kowalewski, D., Muszyńska, E. \& Adamiak, A., 2009. Season's influence on the properties of male domestic pig semen. Rozprawy naukowe Pope John Paul II State School of Higher Vocational Education in Biała Podlaska. III, 177-187.

Kondracki, S., Iwanina, M, Wysokińska, A. \& Górski, K., 2013. The use of sexual activity measurements to assess ejaculatory performance of boars. Arch. Tierzucht. 56, 106, 1-13.

Levis, G.D. \& Reicks, L.D., 2005. Assessment of sexual behavior and effect of semen collection pen design and sexual stimulation of boars on behavior and sperm output - a review. Theriogenology 63, 630-642.

Oberlender, G., Murgas, L.D.S., Zangeronimo, M.G., Silva, A.C. \& Pereira, L.J., 2012. Influence of ejaculation time on sperm quality parameters in high performance boars. J. Anim. Sci. Adv. 2, 499-509.

Okere, C., Joseph, A. \& Ezekwe, M., 2005. Seasonal and genotype variations in libido, semen production and quality in artificial insemination boars. J. Anim. Vet. Adv. 4, 885-888.

Pinart, E. \& Puigmulé, M., 2013. Factors affecting boar reproduction testis function and sperm quality. In: Boar Reproduction - Fundamentals and New Biotechnological Trends. Eds: Bonet, S., Casas, I., Holt, V.W. \& Yeste, M., Springer-Verlag, Berlin Heidelberg. pp. 109-202.

SAS, 2002-2003. The SAS System for Windows, Cary, N.C., USA.

Savić, R., Petrović, M., Radojković, D., Radović, Č. \& Parunović, N., 2013. The effect of breed, boar and season on some properties of sperm. Biotechnol. Anim. Husb. 29, 299-310.

Szostak, B. \& Sarzyńska, J., 2011. The influence of the breed and age on the libido of insemination boars. Acta Sci. Pol., Zootechnica 10, 103-110.

Tomiyama, M., Oikawa, T., Arakane, T., Kanetani, T. \& Mori, H., 2008. Analysis of environmental effects in production and reproduction traits on purebred Berkshire in Japan. Res. J. Anim. Sci. 2, 157-163.

Wolf, J. \& Smital, J., 2009a. Effects in genetic evaluation for semen traits in Czech Large White and Czech Landrace boars. Czech J. Anim. Sci. 54, 349-358.

Wolf, J. \& Smital, J., 2009b. Quantification of factors affecting semen traits in artificial insemination boars from animal model analyses. J. Anim. Sci. 87, 1620-1627.

Wysokińska, A. \& Kondracki, S., 2014. Assessment of sexual activity levels and their association with ejaculate parameters in two-breed hybrids and purebred Duroc and Pietrain boars. Ann. Anim. Sci.14, 559-571. 